\title{
Leontiasis ossea and post traumatic cervical cord contusion in polyostotic fibrous dysplasia Boby Varkey Maramattom*
}

\author{
Address: Department of Neurology, Lourdes Hospital, Kochi, Kerala, India \\ Email: Boby Varkey Maramattom* - bobvarkeys@yahoo.com \\ * Corresponding author
}

Published: 15 August 2006

Head \& Face Medicine 2006, 2:24 doi:10.1 186/1746-160X-2-24

This article is available from: http://www.head-face-med.com/content/2/1/24

(C) 2006 Maramattom; licensee BioMed Central Ltd.

This is an Open Access article distributed under the terms of the Creative Commons Attribution License (http://creativecommons.org/licenses/by/2.0), which permits unrestricted use, distribution, and reproduction in any medium, provided the original work is properly cited.
Received: 29 January 2006

Accepted: 15 August 2006

\begin{abstract}
Leontiasis ossea (leonine facies) or cervical canal stenosis are rare complications of polyostotic fibrous dysplasia (PFD). This case report documents dramatic leontiasis ossea in PFD as well as post traumatic cervical cord contusion due to hyperextension injury in a patient with generalized PFD involving the cranio-facial bones, axial skeleton and entire spine with secondary cervical canal stenosis. Cervical cord contusion has not been reported earlier in PFD.
\end{abstract}

\section{Background}

Fibrous dysplasia (FD) is a rare skeletal developmental disorder whereby the medulla of bone is replaced by fibrous tissue leading to distortion of bony architecture, expansion and weakening of bones, easy fractures, joint subluxations or dislocations and compressive symptoms [1]. Four varieties of FD are recognized; the monostotic form (single bone involvement), polyostotic form (PFD) [multiple bones are affected], craniofacial form (multiple craniofacial bones are affected) or a cherubic form (maxilla and mandible alone are affected). PFD has a predilection for the long bones, ribs, spine and craniofacial bones. It is sometimes associated with the McCune Albright syndrome where café au lait spots and endocrinopathies (particularly precocious puberty) coexist. Rarely, other endocrine dysfunction such as hyperthyroidism, growth hormone excess, Cushing syndrome or primary hyperparathyroidism can also be associated with PFD. Although FD is linked to an activating mutation in the gene that encodes the subunit of stimulatory G protein (Gs) located at 20q13.2-13.3, it is a non-heritable congenital developmental disorder.
Fibrous dysplasia predisposes the spine to atlanto-axial instability [2], odontoid fractures [3], compression fractures, spinal cord compression via expansile lesions $[4,5]$ sarcomatous transformation [6] or scoliosis [7]. Although PFD can produce spinal canal stenosis with consequent pathological implications, cervical cord contusions have never been reported before with this disorder.

I would like to report a case of PFD affecting the entire spine, producing cervical canal stenosis and post traumatic cervical cord contusion. This report is also noteworthy for its dramatic depiction of leontiasis ossea, a peculiar facial deformity sometimes associated with PFD.

\section{Case report}

A 25 year old man was brought to the emergency room (ER) with quadriparesis after a fall from a bicycle. Although he had facial deformities since early childhood, he professed only to cosmetic embarassment, nasal blockage, mouth breathing, mild snoring and progressing bowing of his shins. There were no other affected family members. He was gainfully employed and had been riding a bicycle to work, when he skidded off the road into a 
sand patch, landing on his face. At the point of impact, he bruised his face. He was able to turn over, but immediately noticed some neck pain and weakness of all four limbs. He was just able to lift his arms and move his legs from side to side. He was transferred by ship from his island to our hospital and was seen three days after the injury. On examination, he had leontiasis ossea (leonine facies due to symmetrical frontal and maxillary bossing) (Figure 1). Examination of the oral cavity showed a symmetric soft tissue bulge of the hard palate (Figure 1). He had broad forearms, sausage like fingers and bowing of both legs with saber shins (Figure 2). The nasal bridge was
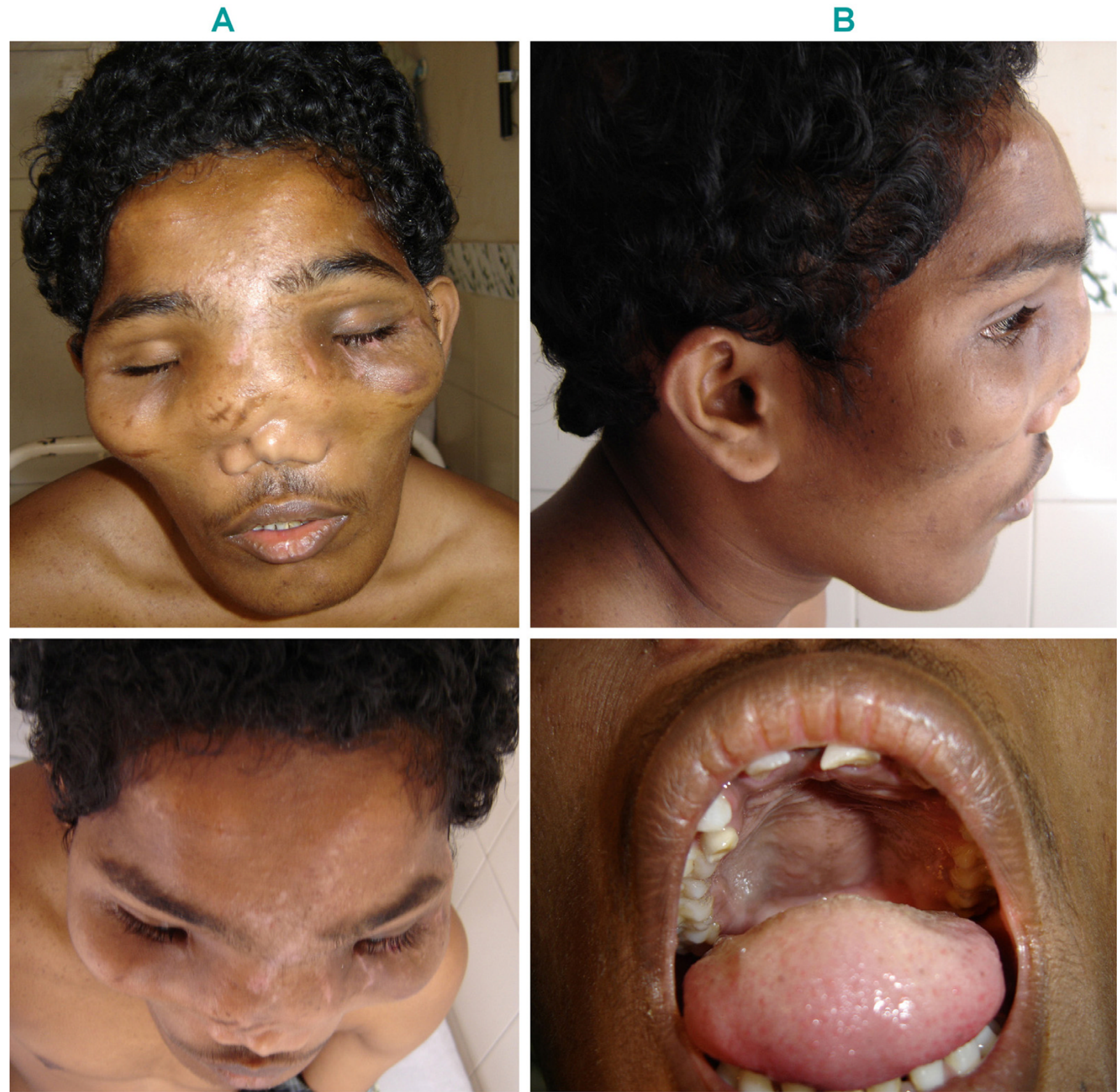

C

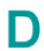

\section{Figure I}

Leontiasis ossea. Panels A-C showing frontal and maxillary bossing. Panel D showing hard palate swelling. 
A
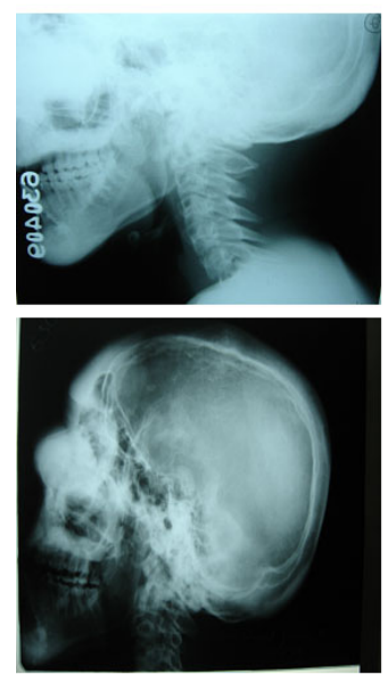

C
B
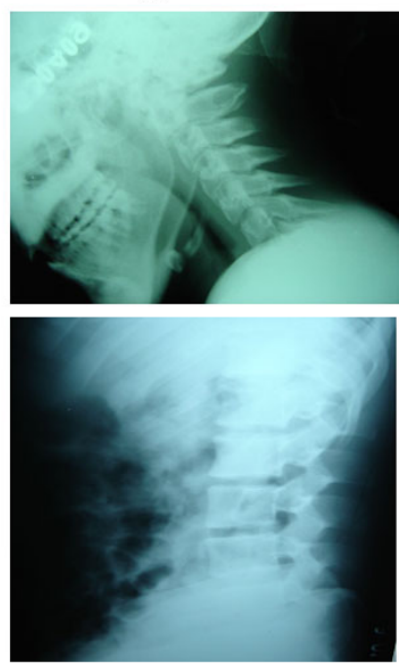

D

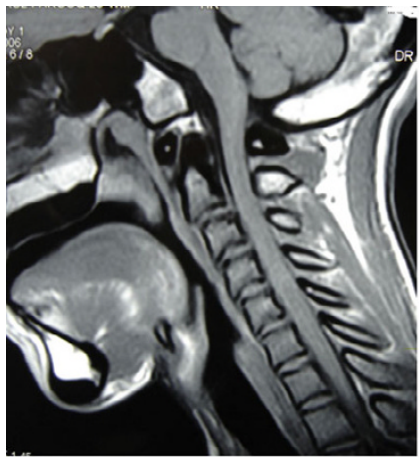

A

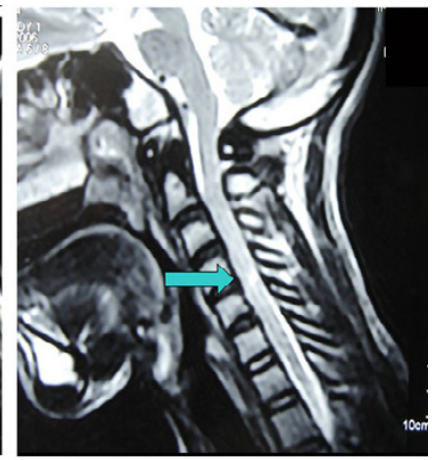

B

\section{Figure 3}

MRI composite Sagittal TI weighted MRI image showing enlargement and hyperintensities involving the posterior elements of the cervical vertebrae. Sagittal T2 weighted MRI image showing a cervical cord contusion at C 4-5 level (Green arrow).

start walking in 5 days. He was discharged home on the $10^{\text {th }}$ day with residual distal hand muscle weakness and grade 4 muscle power in his legs.

\section{Discussion}

Cervical canal stenosis (CCS) predisposes patients to cervical cord injury after traumatic hyperflexion or hyperextension movements. The cervical cord is most mobile between the C3-C6 segments and nearly fills the spinal canal at this level. Hence these segments bear the brunt of injury during cervical spine trauma and patients can develop neuropraxia, cord contusions, hematomas or cord transections. CCS may be developmental or acquired due to a number of causes such as cervical spondylosis, diffuse idiopathic skeletal hyperostosis, ossification of the
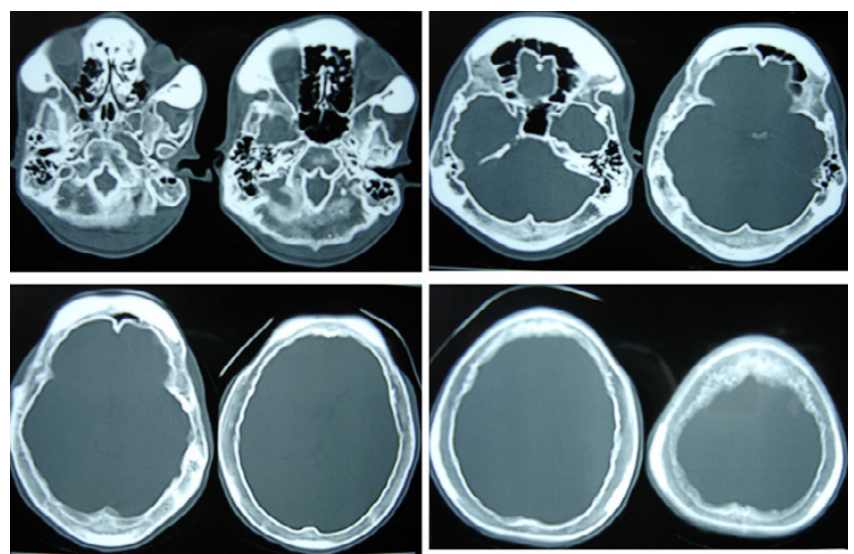

\section{Figure 4}

CT scan bone windows showing diffuse thickening of the skull bones with widening of the diploic space.

absent. The clinico-radiological picture was compatible with a generalized form of PFD. He was initiated on IV methylprednisolone $1 \mathrm{gm}$ OD for 5 days and was able to 
posterior longitudinal ligament (OPLL) or rheumatoid arthritis.

PFD is a rare cause of CCS because it afflicts the lumbar, thoracic, sacral and cervical vertebrae in descending frequency. Nearly $70 \%$ of the lesions involve only the posterior aspects of the spine [8]. The most common abnormality seen in PFD is scoliosis ( $50 \%$ of patients). PFD has rarely been reported to cause pathologic compression fractures of the lumbar spine [9]. Our case is remarkable in that PFD involved the entire vertebral column producing cervical canal stenosis predisposing the patient to cervical cord contusion during hyperextension injury. Another remarkable feature was the leontiasis ossea involving the entire craniofacial skeleton which has rarely been reported [10].

Although the term 'leontiasis ossea' is widely used for localized swellings of the face including those involving the jaw, it should be restricted to a generalized homogenous swelling that implicates most facial bones [11]. True leontiasis ossea is a rare facial deformity that is encountered in polyostotic FD, Albright's syndrome and rarely with Paget's disease, uremia with secondary hyperparathyroidism or acromegaly. Leontiasis ossea can be associated with progressive proptosis, visual impairment or nasal obstruction. Our patient had a relatively asymptomatic leontiasis ossea of long duration with only mild obstructive nasal symptoms, snoring and cosmetic disfigurement.

In conclusion, we present an unusual presentation of PFD with diffuse involvement of the cranio-facio-vertebral skeleton with leontiasis ossea and a post traumatic cervical cord contusion secondary to hyperextension injury of the cord in a compromised cervical canal.

\section{Competing interests}

The author(s) declare that they have no competing interests.

\section{Authors' contributions}

The author was wholly responsible for all aspects of this study including data collection, writing up the paper and takes full responsibility for the integrity of the data and the accuracy of the analyses.

\section{Acknowledgements}

"Written consent was obtained from the patient for publication of study".

\section{References}

I. Leet $\mathrm{Al}$, Chebli C, Kushner $\mathrm{H}$, et al.: Fracture incidence in polyostotic fibrous dysplasia and the McCune-Albright syndrome. J Bone Miner Res 2004, 19:57I-577.

2. Perlick L, Rolf $\mathrm{V}$, Wallny $\mathrm{T}$, Schmitt $\mathrm{O}$ : Atlanto-axial instability presenting a rare complication in fibrous dysplasia - a case report. Unfallchirurg 2000, 103:73-75.
3. Stompro BE, Alksne JF, Press GA: Diagnosis and treatment of an odontoid fracture in a patient with polyostotic fibrous dysplasia: case report. Neurosurgery 1989, 24:905-909.

4. Mezzadri JJ, Acotto CG, Mautalen C, Basso A: Surgical treatment of cervical spine fibrous dysplasia: technical case report and review. Neurosurgery 1999, 44:1342-1346.

5. Montoya G, Evarts CM, Dohn DF: Polyostotic fibrous dysplasia and spinal cord compression. Case report. J Neurosurg 1968, 29:102-105.

6. Yalniz E, Er T, Ozyilmaz F: Fibrous dysplasia of the spine with sarcomatous transformation: a case report and review of the literature. Eur Spine J 1995, 4:372-374.

7. Leet AI, Magur E, Lee JS, Wientroub S, Robey PG, Collins MT: Fibrous dysplasia in the spine: prevalence of lesions and association with scoliosis. J Bone Joint Surg Am 2004, 86:53 I-537.

8. Hoffman KL, Bergman AG, Kohler S: Polyostotic fibrous dysplasia with severe pathologic compression fracture of L2. Skeletal Radiol 1995, 24:160-162.

9. Viljoen DL, Versfeld GA, Losken W, Beighton P: Polyostotic fibrous dysplasia with cranial hyperostosis: new entity or most severe form of polyostotic fibrous dysplasia? Am J Med Genet 1988, 29:661-667.

10. Evans J: Leontiasis ossea; a critical review, with reports of four original cases. J Bone Joint Surg Br 1953, 35:229-243.

II. Dantas M, Costa RS, Jorgetti V, et al.: Facial leontiasis ossea: a rare presentation of hyperparathyroidism secondary to chronic renal insufficiency. Nephron 1991, 58:475-478.

\section{Publish with Biomed Central and every scientist can read your work free of charge}

"BioMed Central will be the most significant development for disseminating the results of biomedical research in our lifetime. " Sir Paul Nurse, Cancer Research UK

Your research papers will be:

- available free of charge to the entire biomedical community

- peer reviewed and published immediately upon acceptance

- cited in PubMed and archived on PubMed Central

- yours - you keep the copyright

Submit your manuscript here:

http://www.biomedcentral.com/info/publishing_adv.asp
BioMedcentral 